\title{
The effect of principal supervision and teacher professional allowances on the competence of elementary school teachers
}

\author{
Hari Suhud ${ }^{1}$, Yasir Arafat ${ }^{2}$, Alhadi Yan Putra ${ }^{2}$ \\ ${ }^{1}$ Sekolah Dasar Negeri 07 Simpang, Indonesia \\ ${ }^{2}$ Universitas PGRI Palembang, Indonesia
}

\begin{tabular}{l} 
Article Info \\
\hline Article history: \\
Received Jul $21^{\text {th }}, 2021$ \\
Revised Aug $5^{\text {th }}, 2021$ \\
Accepted Aug $30^{\text {th }}, 2021$ \\
\hline
\end{tabular}

\section{Keyword:}

Principal supervision

Teacher professional allowances

Teacher professional competence

\begin{abstract}
This study aims to find out the influence of supervision of principals and teacher professional allowances on the professional competence of teachers in Simpang District Ogan Komering Ulu Selatan both partially and simultaneously. The population in this study is 38 elementary school teachers in the Simpang sub-district who have received teacher professional benefits. This research uses quantitative research, with a type of Non-Probability sampling research, the technique used is the saturated Sampling technique. Data collection techniques using closed questionnaires. Data analysis with ttest and F test showed that: Supervision of the principal has an influence on the professional competence of teachers in Simpang sub-district by $20.90 \%$; Teacher professional allowance has an influence on the professional competence of teachers in Simpang subdistrict by $20.50 \%$, and supervision of principals and teacher professional allowances have a simultaneous influence of $45.90 \%$ on the professional competence of elementary school teachers in Simpang District Ogan Komering Ulu Selatan.
\end{abstract}

C 2021 The Authors. Published by IICET.

This is an open access article under the CC BY-NC-SA license

(https://creativecommons.org/licenses/by-nc-sa/4.0

\section{Corresponding Author:}

Suhud, H.,

Sekolah Dasar Negeri 07 Simpang, Indonesia

Email: harisuhud25@gmail.com

\section{Introduction}

The Political and Economic Risk Consultant announced the results of the Indonesia Education Quality Study, the results of which suggested that Indonesia was ranked 12th out of 12 countries, In addition to the above study, there are several other studies that state that Indonesia's standard of education is still low. The Indonesian government has released different policies on the standard of education based on the facts. The government has issued laws, government regulations, ministerial regulations to regional regulations. To improve the quality of national education, the Indonesian government has also issued various strategies, [1] including improving the competence of teachers as the spearhead of education in Indonesia. The standard of teachers is one of the big keys to the success of education [1].

[2] In schools and also in the world of education, teachers are very important positions and roles. The teacher provides a picture of personality and noble character for students, namely teachers who are willing to set aside their time, for the benefit of their students, from guiding, sharing experiences, ideas, chatting and helping students in facing difficulties that can hinder their learning activities. As teachers/educators, teachers are the dominant factor in determining the success of any efforts to advance education. Therefore, in every effort to update education, it always starts with the teacher factor. Teachers are the spearhead in the 
development of national education, especially in building and improving the quality of human resources through formal education. Improving the quality of teachers needs to be done continuously.

The professional competence of teachers is also affected in the educational process by the position of the principal. [3] The principal is the person responsible for the administration of education, school administration, the coaching of other education employees, the use and maintenance of facilities and equipment, as well as the school supervisors he runs [4]

The principal as the highest leader in the school is declared successful if he can improve the quality and performance of teachers through various forms of coaching activities for teachers in carrying out the learning process at school. As an education advisor, education manager, education supervisor, education administrator, coaching other educational staff and the use and maintenance of facilities and infrastructure, the roles of the principal must be able to carry out tasks and responsibilities [4]

As the principal supervisor, the principal must be able to carry out coaching through the supervision of all teachers and education personnel they lead, to create a meaningful work atmosphere in the education unit. The leadership of the principal determines the quality, without good leadership the quality improvement process cannot be carried out and realized [7]

The teacher welfare aspect also causes the quality of teacher professionalism to increase. According to F.W.Taylor in Soleha [5] that the desire to fulfill their needs causes people to want to work hard. Teacher Professional Allowances are government efforts to improve teacher welfare, this policy is given to teachers who have been certified through professional education.

The teacher certification program guarantees which teacher performance is enhanced in the competent execution of teaching tasks. Teacher certification is a competency test process designed to reveal one's mastery of competence as a basis for providing teacher certification [4] With the teacher professional allowance, it is hoped that an increase in the quality of learning and the professional competence of teachers in schools.

Based on the description above, this research needs to be investigated to reveal the research problem entitled: "The Effect of Principal Supervision and Teacher Professional Allowances on the Professional Competence of Primary School Teachers in Simpang District, Ogan Komering Ulu Selatan Regency".

\section{Method}

The type of research used in this research is Non Probability sampling, that is, each population group does not get the same opportunity or opportunity as the sample, while the technique used is the saturated sampling technique, which is a sample that represents the total population (Sugiono, 2015)

The subjects in this study were 38 elementary school teachers in the Simpang sub-district, Ogan Komering Ulu Selatan district who had received the professional teacher allowance. The research data were obtained by using a questionnaire to determine the effect of the variable of principal supervision and teacher professional allowances on teacher professional competence. The instrument used has been validated through internal validity, content validity, and construct validity. Content validity was obtained from experts and construct validity from field trial results. The questionnaire trial was conducted on 20 elementary school teachers in Buana Pemaca District who had received the professional teacher allowance.

The results of the instrument trial were analyzed using IBM SPSS 25.0. The reliability of the instrument in this study was obtained from Cronbach's alpha testing of the principal's supervision data and teacher professional allowances. Principal supervision data and teacher professional allowances were analyzed through descriptive analysis and hypothesis testing consisting of the $\mathrm{f}$ test and $\mathrm{t}$ test.

\section{Results and Discussions}

The first hypothesis to be carried out is the hypothesis which states that there is an effect of principal supervision on the professional competence of elementary school teachers in Simpang District, Ogan Komering Ulu Selatan Regency. This hypothesis is proven by the existence of a partial correlation tcount $3.545>$ ttable 2.030 at a significant level $\alpha=0.05$, with a significance value of $0.001<0.05$. So it can be concluded that $\mathrm{H} 0$ is rejected and $\mathrm{H} 1$ is accepted, which means. Principal supervision (X1) affects the professional competence of elementary school teachers $(\mathrm{Y})$ in Simpang District, Ogan Komering Ulu Selatan Regency. 
Table $1<$ The Coefficient of Determination of Principal Supervision and Teacher Professional Competence>

\begin{tabular}{ccccc}
\hline & \multicolumn{2}{c}{ Model Summary } & Std. Error of the \\
Model & $\mathrm{R}$ & R Square & Adjusted R Square & Estimate \\
1 & $.509^{\mathrm{a}}$ & .259 & .238 & 3.63319 \\
\hline
\end{tabular}

a. Predictors: (Constant), Supervision of the Principal

Based on the results of hypothesis testing, it is known that the R Square value is 0.259 from the correlation coefficient (R) of 0.509 . This means that the influence of the independent variable on the dependent variable shows a value of 0.259 which means that the principal's supervision variable (X1) which means has an influence on the variable of teacher professional competence (Y) Elementary Schools in Simpang District, South OKU Regency of $25.90 \%$, while the remaining $74.10 \%$ is influenced by other factors.

The second hypothesis testing is the hypothesis which states that there is an effect of teacher professional allowances on the professional competence of elementary school teachers in Simpang District, Ogan Komering Ulu Selatan Regency. This hypothesis is proven by the partial correlation value of tcount 3.046> ttable 2.030 at a significant level $\alpha=0.05$, with a significance value of $0.004<0.05$, So it can be concluded that $\mathrm{H} 0$ is rejected and $\mathrm{H} 1$ is accepted, which means that the professional teacher allowance (X2) affects the professional competence of teachers $(\mathrm{Y})$ in elementary schools in Simpang District, Ogan Komering Ulu Selatan Regency.

Table $<$ Coefficient of Determination of Teacher Professional Allowances and Teacher Professional

Competence>

\section{Model Summary}

Model R R Square Adjusted R Square Std. Error of the Estimate
$.453^{\mathrm{a}}$
.205
.183
3.76285

a. Predictors: (Constant), Teacher Professional Allowance

Based on the results of hypothesis testing, it is known that the R Square value is 0.205 from the correlation coefficient $(\mathrm{R})$ of 0.453 . This means that the influence of the independent variable on the dependent variable shows a value of 0.205 , which means that the teacher professional allowance variable (X2) has an influence on the teacher professional competence variable $(\mathrm{Y})$ in Elementary Schools in Simpang District, OKU Selatan Regency by $20.50 \%$, while the rest is equal to $79.50 \%$ is influenced by other factors.

The third hypothesis which is carried out is the hypothesis which states that there is an effect of principal supervision and teacher professional allowances on the professional competence of primary school teachers in Simpang District, Ogan Komering Ulu Selatan Regency. This hypothesis is proven through the F test with a significance value of $0.000<0.05$ and Fcount 14.871 $>$ Ftable 3.09, So it is concluded that there is an effect of variable $\mathrm{X} 1$ and variable $\mathrm{X} 2$ together on variable $\mathrm{Y}$, which means that there is an effect of principal supervision and teacher professional allowances on the professional competence of primary school teachers in Simpang District, Ogan Komering Ulu Selatan Regency.

Table $3<$ Coefficient of Determination of Principal Supervision and Teacher Professional Allowances on

Professional Competence>

\begin{tabular}{lrrrrr}
\hline \multirow{3}{*}{ Model } & \multicolumn{4}{c}{ Model Summary } \\
1 & $\mathrm{R}$ & R Square & Adjusted R Square & Std. Error of the Estimate \\
\hline & & $.678^{\mathrm{a}}$ & .459 & .428 & 3.14676 \\
\hline
\end{tabular}

a. Predictors: (Constant), Teacher Professional Allowances, supervision of the Principal

Based on the results of hypothesis testing, it is known that the R Square value is 0.459 from the correlation coefficient (R) of 0.678 . This means that the magnitude of the independent variable's effect on the dependent variable shows a value of 0.459. This means that in Elementary Schools in Simpang District, South OKU Regency, the main supervision variable (X1) and the professional teacher allowance (X2) have an effect of $45.90 \%$ on the professional teacher competence variable $(\mathrm{Y})$. 


\section{Conclusions}

Based on the results of data analysis and discussion through proving the hypothesis which includes three variables, namely the supervision of the principal (X1), the Professional Teacher Allowance (X2) and the Professional Competence of Teachers (Y), it can be concluded that: (1) Supervision of the principal has a 25.90 $\%$ influence on the professional competence of elementary school teachers in the Simpang District, South OKU Regency, (2). There is an influence between the professional allowance for teachers on the professional competence of elementary school teachers in Simpang District, OKU Selatan Regency of $20.50 \%$, (3) There was an effect of principal supervision and professional teacher allowances on the professional competence of elementary school teachers in Simpang District, Ogan Komering Ulu Selatan Regency simultaneously at $45.90 \%$.

\section{References}

Fattah, N. (2000). Manajemen Berbasis Sekolah. Bandung: Andika.

Gustina, L. (2016). Pengaruh Sertifikasi Guru Terhadap Kinerja Guru (Studi Pada Guru Tersertifikasi di SD Negeri 2 Tanjung Senang, Kelurahan Tanjung Senang, Kecamatan Tanjung Senang. Bandar Lampung: University of Lampung.

Mulyasa, E. (2015). Managemen Dan Kepemimpianan Kepala Sekolah. Jakarta: Bumi Aksara.

Mulyasa, E. (2013). standar kompetensi dan sertifikasi guru. Bandung: remaja rosdakarya.

Soleha, Z. (2019). Pengaruh Tunjangan Sertifikasi Terhadap Kompetensi Kepribadian Guru Pendidikan Agama Islam di MAN 2 Lebong. Bengkulu: IAIN Curup.

Sugiono, P. (2015). Metode penelitian kuantitatif kualitatif dan R dan D. Bandung: Alfa Beta.

Suwandi. (2016). Pengaruh Kepemimpinan Kepala Sekolah, Budaya Kerja Dan Komitmen Kerja Terhadap Rofesionalisme Guru di Smp Negeri Kecamatan Sumberejo Kabupaten Tanggamus. Lampung: Lampung University. 